\title{
AKTUÁlNE OTÁzKY EFEKTÍVNOSTI, ROVNOSTI A KVALITY VO VZDELÁVACOM PROSTREDÍ
}

\author{
Iveta Dudová, Simona Polonyová
}

\author{
Kl’účové slova: \\ vzdelanie, vzdelávacia politika, efektívnost', kvalita, rovnost', vzdelávací systém
}

\section{Key words:}

education, education policy, efficiency, quality, equality, education system

\begin{abstract}
Abstrakt
Globalizácia, technologické a organizačné zmeny, demografický vývoj a migračné toky predstavujú výzvy, na ktoré musia vzdelávacie inštitúcie reagovat', aby študujúci po skončení štúdia disponovali širokou škálou požadovaných kl'účových kompetencií a zručností. Politiky vzdelávania a odbornej prípravy môžu mat' pozitívny dopad na dosahovanie trvalo udržatel'ného rozvoja, konkurencieschopnosti, sociálnej kohézii a na zamestnanost'. Príspevok sa zameriava na efektívnost', kvalitu a rovnost' $\mathrm{v}$ európskych systémoch vzdelávania a odbornej prípravy. Ciel'om je analyzovat' spomínané pojmy a poskytnút' prehl'ad politickej spolupráce na európskej úrovni prostredníctvom pracovných programov (Vzdelávanie a odborná príprava 2010, Aktualizovaný strategický rámec európskej spolupráce v oblasti vzdelávania a odbornej prípravy - ET 2020). Načrtáva aj dva hlavné ciele vzdelávacej politiky - ciele efektívnej alokácie a ciele týkajúce sa spravodlivej distribúcie.
\end{abstract}

\begin{abstract}
Globalisation, organisational and technological changes, demographic developments and migration flows challenge education institutions to equip learners with a wide range of key competences and skills. In this context, education and training policies can have a positive impact on sustainable development, competitiveness, social cohesion and employment. The main topics of this paper are efficiency, quality and equality in European education and training systems. This paper aims to analyse the concepts of efficiency, quality and equality of education and training and to offer an overview of the political cooperation through work programs (the Education and Training work programme - ET 2010, the Strategic framework for European cooperation in education and training - ET 2020) at the European level. It also outlines the two main goals of education policy - both goals of efficient allocation and goals of equitable distribution.
\end{abstract}

\section{Úvod}

Dopad spoločenských a ekonomických vplyvov zosilňuje možné priaznivé pôsobenie politiky vzdelávania a odbornej prípravy na trvalú udržatel'nost', zamestnanost' a ekonomickú prosperitu v podobe zavádzania nových spôsobov organizácie vzdelávania, inovatívnych metód, kl’účových kompetencií učitel'ov a študentov. Modernizácia vzdelávacích systémov by mala poskytnút' odpoved' na to, čo študent potrebuje vediet' a ako l'ahko sa dokáže uplatnit' na pracovnom trhu s vedomost'ami a zručnost’ami, ktorými disponuje po skončení štúdia. Okrem formálneho vzdelávania $\mathrm{v}$ zmysle podpory zavádzania celoživotného vzdelávania v jednotlivých krajinách sa do centra pozornosti dostáva motivácia jednotlivcov k neformálnemu vzdelávaniu $\mathrm{v}$ priebehu celého života. V záujme toho by mali byt' reformy 
európskych vzdelávacích systémov založené na rovnosti, efektívnosti a väčšej kvalite. $\mathrm{V}$ príspevku sa zaoberáme hlbšou analýzou spomínaných determinantov a ich implikovaním do politík vzdelávania a odbornej prípravy v EÚ. Prezentujeme základné dôvody modifikácie vzdelávacích systémov smerom $\mathrm{k}$ väčšej efektívnosti, rovnosti a kvalite, pričom sa opierame o najnovšie výsledky analýz realizovaných Európskym strediskom pre rozvoj odborného vzdelávania (CEDEFOP) a siete EENEE. Uvádzame príklady zaujímavých a účinných metód a prístupov na podporu rozvoja kl'účových kompetencií študentov s perspektívou celoživotného vzdelávania, na podporu rozvoja schopností učitel'ov a vedenia škôl.

\section{Spoločenské a ekonomické vplyvy modifikujúce systémy vzdelávania v EÚ}

Silnejúca miera globalizácie, vývoj demografických trendov, ako aj prejavujúci sa dopad technického pokroku, následné zmeny $\mathrm{v}$ organizácii práce a využívanie informačných technológií sú výzvy, ktoré so sebou prinášajú potrebu modifikovat' strategické oblasti pre d'alší rozvoj, udržatel'nost' a konkurencieschopnost' ekonomík jednotlivých krajín.

Budúci vývoj v EÚ bude vo vel'kej miere ovplyvnený štyrmi základnými kritickými faktormi - demografické a populačné zmeny, nové tlaky globálnej konkurencie, dlhodobá perspektíva sociálnej kohézie a uplatnenie inovácií v existujúcej politickej realite.

Budúca pracovná sila $\mathrm{v}$ Európe bude čoraz viac tvorená staršou populáciou. To vyvoláva potrebu zlepšit' systém vzdelávania, najmä pre túto skupinu, pretože hospodársky rast $\mathrm{v}$ Európe bude výrazne závisiet' od ich výkonnosti na trhu práce. Proces starnutia sa týka všetkých skupín spoločnosti. Medzi najvýznamnejšie dôsledky demografických zmien pre vzdelávací systém patria účinné prispôsobenie sa celého vzdelávacieho systému, školenia seniorov, starnutie učitel'ov a riešenie migrácie - odliv mozgov a ich získavanie (Brain Drain a Brain Gain). Aj napriek potenciálnemu významu vzdelávania, incidencia odbornej prípravy klesá v závislosti od veku. Jedným z dôvodov je to, že čas na trhu práce je často príliš krátky na kompenzáciu nákladov na investície, najmä ak sú tieto náklady hradené zamestnávatel'om. Okrem toho bude budúcnost' obyvatel'ov európskych krajín charakteristická vel'kými migračnými tokmi do a z EÚ (Brain Drain a Brain Gain). Emigrácia vysoko kvalifikovaných jednotlivcov, najmä mladých absolventov vysokých škôl do krajín mimo Európskej únie predstavuje významné riziko pre konkurencieschopnost' Európy.

Najvýznamnejšie dôsledky globálnej konkurencie pre vzdelávací systém možno vymedzit' ako posilnenie vysoko kvalifikovanej práce, zvýšenie kvality učitel'ov a potreba vzdelávania v prospech inovácií. Vysoká úroveň l'udského kapitálu je potrebná pre sofistikovaný výrobný proces výrobkov a služieb, ako aj pre inováciu nových produktov a procesov. Tento posledný aspekt je mimoriadne významný, ako zdôrazňujú nové rastové teórie, dlhodobý rast je poháňaný inováciami. Nové tlaky globálnej konkurencie vytvoria väčší tlak na udržanie sociálnej súdržnosti v Európe.

Vzhl'adom na to, že distribúcia vzdelávania je vel'mi dôležitá pre spoločenské nerovnosti, vzdelávací systém je kl'účovou inštitúciou ovplyvňujúcou sociálnu súdržnost'. Európa preto čelí d’alšej výzve z hl'adiska dlhodobej perspektívy - zlepšit' sociálnu súdržnost' vhodným vývojom vzdelávacích systémov. 
V súčasných podmienkach, zvyšujúca sa nezamestnanost' ako jeden z hlavných sociálnych dopadov hospodárskeho poklesu v jednotlivých krajinách zosilňuje pri výhl'adoch do budúcnosti význam zvyšovania úrovne zručností prostredníctvom celoživotného vzdelávania, dôležitú úlohu celoživotného poradenstva či možnosti rekvalifikácie s ciel'om ul'ahčit' vyhliadky na opätovné pracovné zaradenie. Podl'a najnovšej analýzy zameranej na budúce trendy požadovaných zručností pre uplatnenie sa na pracovnom trhu vypracovanej Európskym strediskom pre rozvoj odborného vzdelávania (CEDEFOP), v nasledujúcom desat'ročí by mal v európskych krajinách (analýza zahŕňa členské krajiny EÚ 27 + Nórsko a Švajčiarsko) podiel pracovných miest s požadovanou vyššou kvalifikáciou vzrást’ z 29,4 \% na $35,2 \%$, podiel pracovných miest so stredným stupňom vzdelania by mal zostat' nezmenený, ale nad'alej značný $(50,3 \%)$, zatial' čo podiel pracovných miest s nízkou kvalifikáciou zaznamená klesajúci trend z 20,3 \% na 14,5 \%. Pokial' ide o jednotlivé sektory, pokles pracovných miest zaznamená primárny sektor (z 6,5\% na 5,1\%), spracovatel'ský priemysel a stavebníctvo (z 22,9 \% na 21,3\%). Priaznivý vývoj zaznamená sektor služieb (nárast z 70,7 \% na $74 \%$ ), predovšetkým obchodné služby. Z toho vyplýva, jednoznačný dôraz na participáciu na celoživotnom vzdelávaní, a to najmä u osôb s nízkou úrovňou dosiahnutého vzdelania ako najviac ohrozených na pracovnom trhu. Dostupné európske štatistické údaje však poukazujú na pokles a následnú stagnáciu vo vývojových trendoch účasti na celoživotnom vzdelávaní, a preto je potrebné realizovat' aj nad'alej kroky smerom k pozitívnejším výsledkom. V roku 2008 percentuálny podiel osôb vo vekovej skupine 25 - 64 - ročných predstavoval len 9,5 \%, hoci v európskom pracovnom programe Vzdelávanie a odborná príprava 2010 sa uvádzala referenčná hodnota EÚ pre rok 2010 12,5\%. Navyše (nad'alej vychádzame z analýz vypracovaných CEDEFOP) prevažuje podiel osôb s vyšším stupňom vzdelávania nad osobami s nízkou kvalifikáciou a staršími pracovníkmi. Participáciu na celoživotnom vzdelaní u osôb vo veku 25 - 64 rokov v EÚ 27 v rokoch 2001 až 2008 odzrkadl'uje aj nasledujúci graf 1 . Z grafu možno konštatovat' mierne klesajúci trend od roku 2005 z 9,8 \% na 9,7 \% v roku 2006 a následnú stagnáciu v rokoch 2007 a 2008 (9,5 $\%)$. V grafe sú uvedené tiež referenčné hodnoty pre rok 2010 a pre nasledujúce desat'ročie, ktoré by mali byt' dosiahnuté v rámci EÚ v roku 2020 (ich podrobnejšie pochopenie a d'alšie aktivity EÚ $\mathrm{v}$ podobe prijatých pracovných programov zameraných na potrebu efektívneho a kvalitného vzdelávania analyzujeme v nasledujúcej kapitole).

Graf 1 Miera celoživotného vzdelávania dospelých v \% v EÚ 27 (vo veku 25 - 64 rokov)

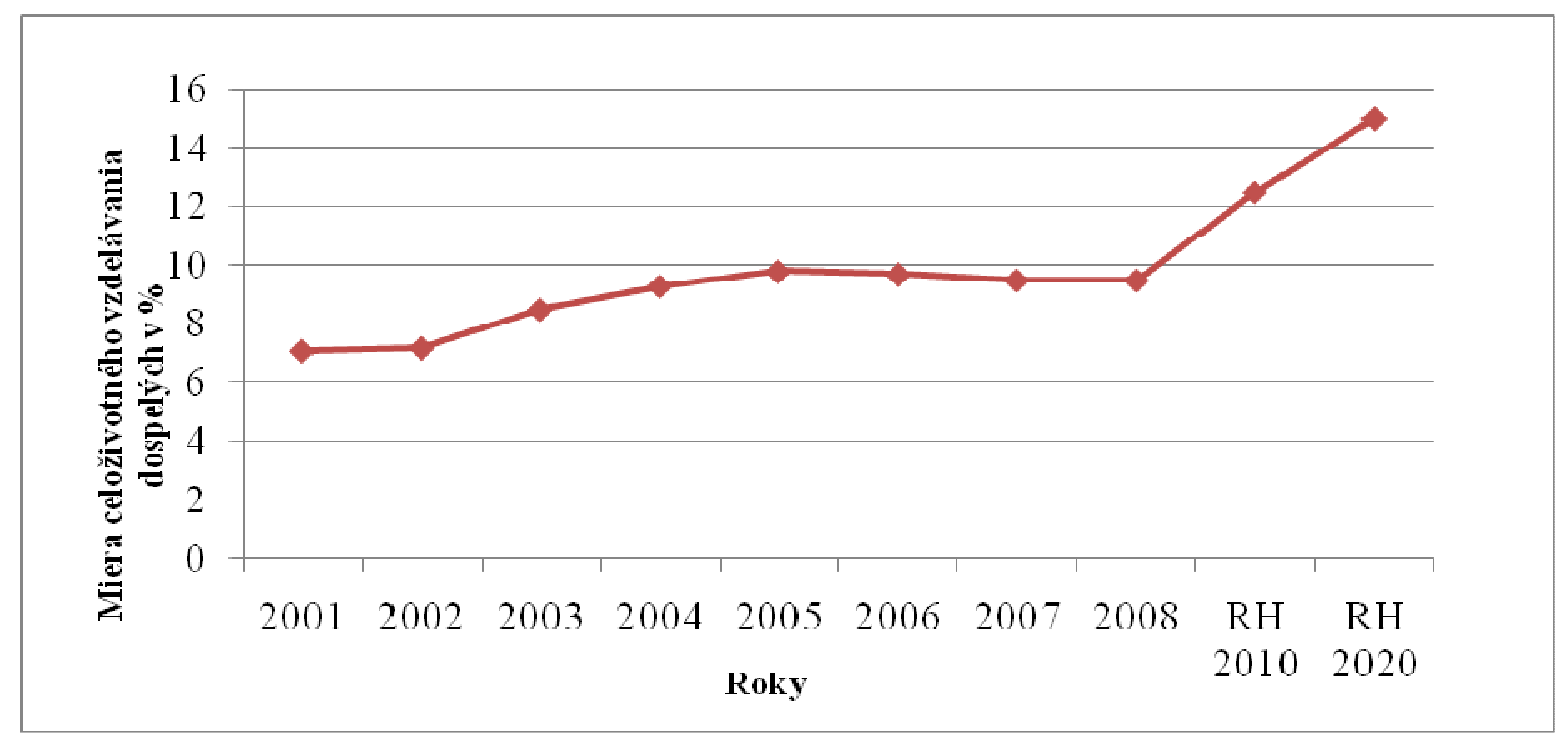

Prameň: Eurostat, CEDEFOP, vlastné spracovanie 
Z uvedenej analýzy vyplýva, že očakávaný budúci pokles dopytu po nekvalifikovanej pracovnej sile bude nad'alej podporovat' význam vzdelania v jednotlivých fázach vzdelávacej dráhy, ked’že vzdelávanie môže slúžit' ako základ pre sociálne integrácie a ako najlepšie záruky možné proti vylúčeniu, nezamestnanosti a diskriminácii. V tejto súvislosti, sa do popredia dostáva otázka efektívnych investícií do vzdelávania a ich návratnost' v jednotlivých fázach životného cyklu. Investície do vzdelania na jednom stupni zvyšujú nielen priamo zručnosti dosiahnuté $\mathrm{v}$ tomto štádiu, ale nepriamo aj ich produktivitu, ktorou bude vzdelávacími investíciami $\mathrm{v}$ d’alšej fáze premenená na ešte viac zručností. Vzdelanie je dynamický synergický proces, $\mathrm{v}$ ktorom učenie $\mathrm{v}$ ranom veku vyvoláva učenie $\mathrm{v}$ neskoršom období života. Návratnost' vzdelávacích investícií v ranom detstve je najvyššia, pretože ul'ahčujú neskoršie vzdelávanie. To výrazne ovplyvňuje efektívnost' a rovnost' vo vzdelávacom systéme. V politikách na podporu l'udského kapitálu sú opatrenia $\mathrm{v}$ raných fázach obzvlášt' dôležité a ich nedostatky sa môžu rozvinút' v neskorých štádiách. Okrem toho návratnost' skorej intervencie je mimoriadne vysoká pre deti zo znevýhodneného prostredia, ktoré doma nezískali zručnosti potrebné $\mathrm{k}$ úspešnosti $\mathrm{v}$ neskorších stupňoch vzdelávania. Takéto zásahy nielen formujú zručnosti, ale budujú aj základy ovplyvňujúce zvýšenú produktívnost' vzdelávania v neskoršom období života vd’aka komplementárnosti vzdelávania v priebehu životného cyklu. V neskorších fázach životného cyklu je návratnost' investícií do vzdelávania nižšia. Medzi dôvody patrí kratší časový horizont, počas ktorého môžu využívat' pozitívne efekty účinky vzdelávania a zručnosti získané prostredníctvom odbornej prípravy a vzdelávania dospelých môžu byt' t’ažšie certifikované. Návratnost' investície do vzdelávania v neskorej fáze vzdelávacieho cyklu je obzvlášt' nízka pre l'udí, ktorým chýbajú zručnosti. [10].

\section{Graf 2 Návratnost’ investícií do vzdelávania na rôznych úrovniach vzdelávacieho systému}

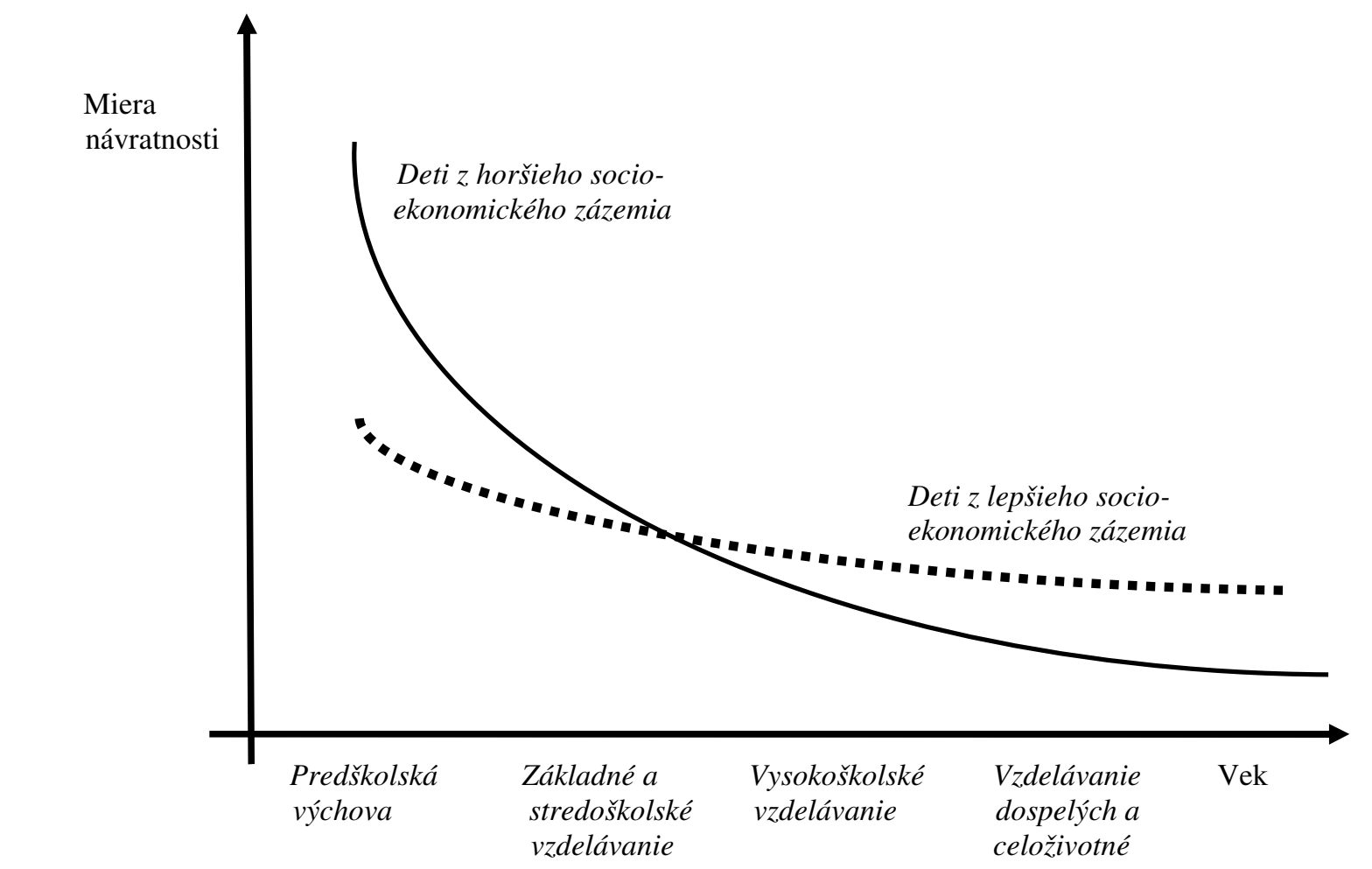

Prameň: Cunha a kolektív, EENEE 2006

Obrázok graficky znázorňuje základný model životného cyklu politík v oblasti vzdelávania a odbornej prípravy pokial' ide o efektívnost' a spravodlivost'. Miera návratnosti v mladom veku má tendenciu byt' vyššia u detí zo znevýhodnených rodín, ale vo vyššom veku zase 
vyššia pre deti pochádzajúce $\mathrm{z}$ dobrého sociálno-ekonomického zázemia. Je preto dôležité všeobecne zaviest' a inštitucionalizovat' vzdelávanie v ranom detstve, najmä pre tých, ktorí sú znevýhodnení a nemajú doma podnetné výchovné prostredie. Takáto politika musí byt' spojená s mechanizmami kontroly kvality v predškolskom vzdelávaní a dennej starostlivosti. Okrem raného zabezpečenia rovnosti príležitostí jednotlivci by mali vo vzdelávaní zotrvat' primeraný čas. Pretože vzdelanie je determinantom sociálneho a ekonomického blahobytu v budúcnosti, je dôležité riešit' problém predčasného ukončenia školskej dochádzky. Medzi najvýznamnejšie dôsledky potreby dlhodobého udržania sociálnej inklúzie pre vzdelávací systém možno zaradit' posilnenie vzdelávania v ranom detstve, znižovanie miery predčasného ukončenia školskej dochádzky, integrácia imigrantov prostredníctvom vzdelávania a motivácia pre vzdelávanie.

Tieto oblasti budú mat' vážne dôsledky pre vzdelávacie politiky. Vzhl'adom na meniacu sa štruktúru obyvatel'stva sú potrebné úpravy na všetkých úrovniach vzdelávacieho systému. Európske vzdelávacie systémy by sa mali modifikovat' smerom k rovnosti, efektívnosti a väčšej kvalite, ked’že efektívne nadobudnuté vedomosti a zručnosti môžu významne determinovat' udržatel'nost' rastu, vytváranie nových pracovných miest a konkurencieschopnost' hospodárstva ako celku.

\section{Koncept rovnosti, efektívnosti a kvality vo vzdelávacom prostredí}

V prostredí ekonómov vzdelávania a najvyšších predstavitel'ov EÚ sa v poslednom období definovali kritické faktory vo vzdelávacích systémoch, ktoré môžu výrazne ovplyvnit' konkurencieschopnost' a sociálnu kohéziu. Sú to predovšetkým efektívnost' a rovnost' v systémoch vzdelávania, ktoré sú spojené s potrebou zvyšovania kvality vo vzdelávaní. Koncept rovnosti vo vzdelávaní je pomerne t’ažké definovat' presne, ale vo všeobecnosti sa vel'mi približuje konceptu rovnosti príležitostí. Očakávané vzdelávacie výsledky jednotlivcov by mali závisiet' len od ich študijného úsilia, ale nie od okolností, ktoré nemôžu ovplyvnit' (rasa, pohlavie, rodinné zázemie). So samotnou efektívnost’ou vzdelávania súvisí kvalita vzdelávacích systémov a inštitúcií, v ktorých proces edukácie prebieha. Kvalita a efektívnost' sú vzájomne prepojené, ked’že samotná efektívnost' závisí od kvality vzdelávania. V rámci efektívnosti a kvality vzdelávania sa zdôrazňujú ich najdôležitejšie zložky [3]: získavanie klúčových kompetencií, nové prístupy k riadeniu a vedeniu, výzvy pre učitel’ov.

Ciele vzdelávacej politiky zvyčajne zahŕňajú tak ciele efektívnej alokácie ako aj ciele týkajúce sa spravodlivej distribúcie. Do akej miery by mal byt' každý z týchto ciel'ov naplnený, je vecou politického rozhodnutia a tiež vedeckého hodnotenia. Samozrejme, že ciele efektívnosti a rovnosti nie sú obmedzené len na samotnú vzdelávaciu politiku. Tieto ciele by mali byt' kombinované s ciel'mi d'alších súvisiacich politík, ako je napríklad sociálna politika, politika trhu práce, ale aj migračná politika, ktorej význam vzhl'adom na starnutie európskej populácie a migračné pohyby neustále rastie. Ciele rovnosti, respektíve spravodlivosti možno vyjadrit' v rámci výsledkov vzdelávacieho systému a odbornej prípravy, akými sú napríklad výsledky testov alebo z hl'adiska externého výsledku to môžu byt' výsledky na trhu práce. Hodnotenie rovnosti má vonkajší aspekt, ktorý vyžaduje, aby konkrétny ciel' rovnosti bolo možné lepšie dosiahnut' investíciami do vzdelania ako alternatívnym investovaním, a vnútorný aspekt vyžaduje, aby daný súbor zdrojov v oblasti vzdelávania a odbornej prípravy bol použitý najspravodlivejším spôsobom [10]. 
Na samotnú efektívnost', ako jeden z ciel’ov vzdelávacej politiky, má vplyv niekol'ko faktorov, a to jednak vzdelávacie prostredie, podpora intelektuálnej slobody, podnecovanie, pedagóg, ktorý aplikuje didaktické prostriedky a učebné pomôcky do vyučovacieho procesu, experimentovania a kreativita, podpora sebariadenia vo vzdelávaní, zabezpečenie spätnej väzby vo vzdelávaní a vytyčovanie d’alších ciel'ov vzdelávania [6]. Kvalita uvedených determinantov má potom vplyv na priebeh a výsledky dosahované v edukačnom procese. V záujme zvýšit' ich kvalitatívnu úroveň, krajiny pristupujú k realizácii školských reforiem na národnej úrovni s ciel'om zvýšit' efektívnost' celého procesu vzdelávania a následného „čerpania“ z nadobudnutých vedomostí a zručností v pracovnom prostredí. Pri spätnom zist'ovaní dosahovaného zlepšenia, čiže dosiahnutia vyššej kvality vzdelávania, potom zohráva svoju úlohu hodnotenie a monitorovanie formou sebahodnotenia vzdelávacími inštitúciami či externým zabezpečovaním hodnotenia dosiahnutej kvalitatívnej úrovne. Vzdelávací proces teda pozostáva z niekol'kých etáp, ktorých kvalita a efektívnost' reflektuje vo vzdelávaní [8]:

- plánovanie a vol'ba efektívnych didaktických prostriedkov vzdelávacieho procesu,

- realizácia vyučovacieho procesu zvolenými metódami, formami a učebnými pomôckami,

- evalvácia výučby.

Ako sme už naznačili, nové chápanie filozofie vzdelávania deklarujú všetky oficiálne dokumenty a programy EÚ v oblasti vzdelávania a odbornej prípravy a samotná efektívnost' a kvalita vo vzdelávaní a vzdelávacích systémov ako jeden z kl'účových ciel'ov európskej spolupráce v uvedenej oblasti sa stala ich súčast'ou. Spomínaná spolupráca na európskej úrovni sa $\mathrm{v}$ oblasti vzdelávania a odbornej prípravy začala realizovat' pracovným programom Vzdelávanie a odborná príprava 2010 implementovaného prostredníctvom otvorenej metódy koordinácie, v ktorom sa stanovili tri hlavné strategické ciele, a to ul'ahčit' prístup k vzdelaniu a výchove pre všetkých, zabezpečit' otvorenie vzdelávacích a výchovných systémov širšiemu svetu a zlepšit' ich kvalitu a efektívnost', pričom v rámci tohto ciel'a sa dôraz kládol na zlepšenie kvality vzdelávania učitel'ov a vychovávatel'ov, na rozvíjanie schopností v znalostnej spoločnosti, zabezpečenie prístupu k informačným technológiám, zvýšenie záujmu o vedecké a technické štúdia a efektívne využívanie zdrojov [4]. Zároveň sa stanovili indikátory na meranie pokroku v každom z uvedených ciel'ov a parciálnych ciel'ov, ako aj referenčné hodnoty. Uvedený pracovný program sa stal podporným nástrojom pri uskutočňovaných vnútroštátnych reformách vzdelávacích systémov v jednotlivých členských krajinách. Ked’že sa po zhodnotení dosiahnutých výsledkoch v záverečnej fáze programu zistili aj napriek dosiahnutým pokrokom (revízia obsahu vzdelávania, posilnenie predprimárneho vzdelávania, vypracovanie stratégií celoživotného vzdelávania a zákona o celoživotnom vzdelávaní, pokrok pri rozvoji vnútroštátnych kvalifikačných rámcov) značné rozdiely $\mathrm{v}$ jednotlivých členských krajinách a zároveň nedostatky $\mathrm{v}$ naplňovaní ciel'ov (zvyšovanie výdavkov na vzdelávanie, nedosiahnutie niektorých referenčných hodnôt napr. v oblasti predčasného ukončenia školskej dochádzky alebo účasti dospelých na vzdelávanie), v nasledujúcom desat'ročí sa kladie dôraz na posilnenie úsilia pri ich dosahovaní a plnení.

V súvislosti s takýmto vývojom bol v máji 2009 schválený aktualizovaný strategický rámec európskej spolupráce v oblasti vzdelávania a odbornej prípravy (ET 2020) so štyrmi strategickými výzvami [1]: urobit' z celoživotného vzdelávania a mobility študujúcich realitu, zlepšit' kvalitu a efektívnost' vzdelávania a odbornej prípravy a ich výsledkov, podporovat' spravodlivost', sociálnu súdržnost' a aktívne občianstvo, posilnit' oblast' inovácií a tvorivosti vrátane podnikavosti na všetkých úrovniach vzdelávania a odbornej prípravy. Pre školské 
vzdelávanie, odborné vzdelávanie a prípravu, vysokoškolské vzdelávanie a vzdelávanie dospelých sa stanovuje osobitná agenda. Otázka rovnosti, resp. spravodlivosti vo vzdelávaní je predmetom uplatňovania otvorenej metódy koordinácie vo vzdelávaní a odbornej príprave, problémy pretrvávajú, čo sa prejavuje najmä predčasným opustením vzdelávacieho systému.

Snaha zefektívnit' a skvalitnit' vzdelávanie a výchovu na všetkých stupňoch v školách a tiež v školských zariadeniach $\mathrm{v}$ jednotlivých krajinách teda pretrváva ako jedna z hlavných výziev i v nasledujúcom období. V rámci tejto strategickej výzvy, boli navrhnuté príslušné opatrenia na dosiahnutie kvalitatívnych výsledkov, ktoré by sme mohli zhrnút' nasledovne:

- zabezpečit' väčšiu autonómiu inštitúciám vzdelávania a odbornej prípravy, otvorenost' občianskej spoločnosti a podnikom, zároveň venovat' pozornost' účinným systémom zabezpečovania kvality,

- zabezpečit' efektívnost' a udržatel'nost' využívania zdrojov,

- zamerat' sa na podporou rozvoja kompetencií učitel'ov a na ich profesionálny rozvoj,

- zabezpečit' aby jednotlivec dosahoval kl'účové spôsobilosti,

- zosúlad'ovat' vzdelávanie a odbornú prípravu s novými kvalifikačnými požiadavkami trhov práce v nadväznosti na Iniciatívu „Nové zručnosti pre nové pracovné miesta“, ktorá poukazuje na potrebu účinnejších politík vzdelávania a odbornej prípravy a na posúdenie potrieb nových zručností a nových pracovných miest s ciel'om zmiernit' dopady súčasnej krízy na zamestnanost'.

V záujme zlepšenia rovnosti, efektívnosti a kvality vzdelávania a odbornej prípravy boli zároveň prijaté okrem doterajších aj nové referenčné hodnoty, ktoré sa týkajú zvýšenia počtu detí zúčastňujúcich sa vzdelávania $\mathrm{v}$ ranom detstve a podielu osôb s dosiahnutým vysokoškolským vzdelaním.

Dosiahnut' pokrok v efektívnosti a kvalite ako jednej zo strategických priorít európskej spolupráce vo vzdelávaní a odbornej príprave vyvoláva potrebu poznat' relevantné odpovede na to, akú podobu majú mat' efektívne a kvalitné systémy vzdelávania zohl'adňujúc už spomínané komponenty ako zameranie sa na kl’účové kompetencie, nové prístupy k riadeniu, ako aj vedeniu a výzvy smerom k pedagógom, ked’že kvalita vedenia školy významnou mierou ovplyvňuje tvorbou vzdelávacieho prostredia aj výsledky študentov. Možno konštatovat', že určitý pokrok je už dosahovaný rôznou mierou v jednotlivých európskych krajinách pri vytváraní vzdelávacích programov, pri inovatívnych metódach a postupov, ako aj pri vedení. V tomto roku vydalo Európske stredisko pre rozvoj odborného vzdelávania publikáciu [3], v ktorej sa uvádzajú príklady mnohých aktivít a metód realizovaných v rôznych krajinách na zlepšenie klúčových komponentov kvality a efektívnosti vo vzdelávacích systémov s ciel'om priniest' relevantné informácie a námety pre hlavných aktérov na európskej a vnútroštátnej úrovni $\mathrm{v}$ oblasti vzdelávania a odbornej prípravy a prispiet' ku väčšej kooperácii. $\mathrm{V}$ rámci nových prístupov $\mathrm{k}$ riadeniu a vedeniu ako jeden z komponentov, možno spomenút' príklad tímovej práce vedenia škôl formou tzv. školských klastrov (realizovaný v Belgicku). Śkolský klaster tvorí skupina škôl, ktoré majú medzi sebou uzatvorenú zmluvu o spolupráci na určité obdobie. Školy sa nachádzajú v danom regióne, poskytujú vzdelávanie a výchovu na rovnakom stupni vzdelávania a patria do rovnakej siete vzdelávania (napr. štátne školy, súkromné katolícke školy), hoci riadiace orgány či školské rady nemusia byt' spoločné. Boli zriadené vládou v roku 1999 (na stredných školách) a v roku 2003 (na základných školách). Ich ciel'om je zabezpečit' väčšiu efektívnost' využívaných zdrojov, decentralizáciu a transparentnejšie študijné možnosti v danom regióne. Ich podstatou je, že spolupracujú v niekol'kých oblastiach, a to napr. v zavádzaní nových učebných osnov, 
vo výbere kurzov, v oblasti personálnych otázok, v oblasti zamerania štúdia. Na podporu zvýšenia kvality komunikácie v cudzom jazyku ako jednej z kl'účových kompetencií, mnohé krajiny (aj v SR) aplikujú vo vyučovacom procese metódu CLIL (Content and language integrated learning) - Obsahovo a jazykovo integrované vyučovanie ako inovatívnu vzdelávaciu metódu, ktorej podstatou je vyučovanie nejazykových predmetov prostredníctvom cudzieho jazyka. Zároveň sa vytvára čoraz viac podnetov k profesionálnemu rozvoju učitel'ov na podporu a obnovu ich kompetencií a zlepšenie ich vyučovacích schopností realizovaním napr. jazykového vzdelávania pre učitel'ov, aby počet škôl, ktoré využívajú túto inovatívnu metódu, mohol narastat'. Napr. v Španielsku sa realizuje pre učitel'och základných a stredných škôl trojročný projekt so zameraním na jazykové vzdelávanie. Počas tejto odbornej prípravy sa učitelia spočiatku zoznamujú s metódou CLIL, získavajú teoretické základy, pripravujú materiály, plán výučby (30 hodín v prvom roku odbornej prípravy), následne majú nárok na študijné vol'no v trvaní 10 týždňov v Ústave jazykového vzdelávania v Norwich vo Vel'kej Británii, kde si osvojujú metodické zásady CLIL, ich použitie v triede a rozvíjanie študijných a učebných materiálov.

\section{Záver}

V podmienkach demografických a populačných zmien, nových tlakov globálnej konkurencie a súčasne sa prejavujúcej zvýšenej migrácie, ktorá prináša nové výzvy pre sociálnu súdržnost', ako aj pretrvávajúcich dlhodobých problémov integrácie menšín, v jednotlivých európskych krajinách sa preferuje potreba spravodlivých a inkluzívnych vzdelávacích systémov modifikovaných smerom $\mathrm{k}$ väčšej rovnosti, efektívnosti a kvalite zohl'adňujúc pritom ich hlavné komponenty v podobe získania kl'účových kompetencií, nových prístupov k riadeniu a vedeniu a zvýšenia kvality učitel'ov. Okrem toho, uvedené prejavujúce sa spoločenskoekonomické problémy vytvárajú zároveň priestor pre pôsobenie d'alších súvisiacich politík (sociálna politika, politika trhu práce, migračná politika).

\section{Literatúra:}

[1] Aktualizovaný strategický rámec európskej spolupráce v oblasti vzdelávania a odbornej prípravy [online]. 2008. [cit. 2010-07-06]. Dostupné na internete:

$<$ http://ec.europa.eu/education/lifelong-learning-policy/doc/com865_sk.pdf>.

[2] BENČO, J. 2002. Ekonómia vzdelávania. Bratislava: IRIS, 2002. $185 \mathrm{~s}$. ISBN 80-89018-41-6.

[3] CEDEFOP: Better competences through better teaching and leading. [online]. Luxembourg: Publications Office of the European Union, 2010. 53 s. [cit. 2010-07-09]. Dostupné na internete: <http://www.cedefop.europa.eu/EN/publications/16385.aspx>. ISBN 978-92-896-0644-8.

[4] DUDOVÁ, I. 2009. Ekonómia vzdelávania. Bratislava: EKONÓM, 2009. 167 s. ISBN 978-80-225-2750-7.

[5] CEDEFOP: Skills Supply and Demand in Europe. Medium - Term Forecast up to 2020. [online]. Luxembourg: Publications Office of the European Union, 2010. 120 p. [cit. 2010-07-09]. Dostupné na internete: <http://www.cedefop.europa.eu/en/Files/3052_en.pdf>. ISBN 978-92-896-0536-6.

[6] MATULČÍK, J. - MATULČÍKOVÁ, M. 2009. Vzdelávanie a kariéra. Bratislava: EKONÓM, 2009. 174 s. ISBN 978-80-225-2700-2.

[7] Prístup k právu Európskej únie [online]. Dostupné na internete: <http://eurlex.europa.eu>. 
[8] PROKYPČÁKOVÁ, K. 2005. Zefektívnenie vzdelávanie budúcich učitel’ov. In Příprava učiteli̊ a aktuální proměny v základním vzdelávání: zborník z medzinárodnej konferencie / Renata Jandová. České Budějovice : Jihočeská univerzita, 2005. ISBN 807040-789-1, s.87-89.

[9] The Social Situation in the European Union 2009. [online]. Luxembourg: Publications Office of the European Union, 2010. 357 p. [cit. 2010-07-10]. Dostupné na internete: $<$ http://epp.eurostat.ec.europa.eu/portal/page/portal/product_details/publication?p_prod uct_code=KE-AG-10-001> . ISBN 978-92-79-14159-1.

[10] WÖßMANN, L. - SCHÜTZ, G. 2006. Efficiency and Equity in European Education And Training Systems [online]. European Expert Network on Economics of Education, 2006. 42 p. [cit. 2010-07-10].Dostupné na internete: $<$ http://www.eenee.de/portal/page/portal/EENEEContent/_IMPORT_TELECENTRUM /DOCS/SWP\%20EENEE-Part\%20060426.pdf >.

JEL klasifikace: A20, I2

doc. Ing. Iveta Dudová, PhD.

Docentka

Katedra sociálneho rozvoja a práce

Národohospodárska fakulta

Ekonomická univerzita v Bratislave

Dolnozemská cesta 1, 85235 Bratislava

dudova@euba.sk

\section{Ing. Simona Polonyová}

Interná doktorandka

Katedra sociálneho rozvoja a práce

Národohospodárska fakulta

Ekonomická univerzita v Bratislave

Dolnozemská cesta 1, 85235 Bratislava

s.polonyova@gmail.com 